\title{
Органические нелинейно-оптические материалы на основе дендронизованных полифтортрифенилпиразолин-дицианоизофороновых хромофоров
}

В.В. Шелковников ${ }^{1}$, С.Л. Микерин ${ }^{2}$, А.Э. Симанчук ${ }^{2}$, П.А. Чубаков ${ }^{2}$, Н.В. Васильева ${ }^{1}$, С.В. Коротаев ${ }^{1}$, Н.А. Орлова ${ }^{1}$, В.Н. Бережная ${ }^{1}$, И.Ю. Каргаполова ${ }^{1}$, А.М. Максимов ${ }^{1}$, Р.А. Ищенко ${ }^{1}$, Н.Д. Рязанов ${ }^{1}$

${ }^{1}$ N. N. Vorozhtsov Novosibirsk Institute of Organic Chemistry, Siberian Branch of the Russian Academy of Sciences, 9 prosp. Akad. Lavrenteva, 630090 Novosibirsk, Russian Federation

${ }^{2}$ Institute of Automation and Electrometry, Siberian Branch of the Russian Academy of Sciences,

1 prosp. Akad. Koptyuga, 630090 Novosibirsk, Russian Federation тел:+8 (383) 330-89-96, эл. почта: vice@nioch.nsc.ru

DOI 10.34077/RCSP2021-124

Материалы с квадратичной оптической нелинейностью на основе донорно-акцепторных хромофоров обладают большим потенциалом применения в оптико-электронных модуляторах [1-3]. Для проявления нелинейно-оптических свойств ацентрическия несимметричная ориентация хромофоров в полимерной матрице наводится внешним электрическим полем в ходе полинга. Для достижения высоких значений нелинейного отклика необходимо обеспечить высокую концетрацию хромофоров в полимерной матрице. Дендронизованные структуры синтезированных Д-А красителей позволяют достичь высоких концентраций хромофоров в полимере.

Получены новые нелинейно-оптические материалы на основеполикарбоната и полифтортрифенилпиразолин дицианоизофороновых красителей с арилсульфанильными дендронными заместителями.



Полингованные образцы плёнок толщиной 1,5 мкм демонстрируют $\mathrm{d}_{33}$ до 80 пм/В при концентрации хромофоров $2,5 \cdot 10^{20}$ $\mathrm{cm}^{-3}$. Они обладают высокой временной и температурной стабильностью нелинейного отклика.

При хранении при комнатной температуре в течение месяца для всех красителей характерен небольшой спад отклика на 5-7\%, который происходит в течение первой недели, далее отклик стабилизируется и не спадает за месяц хранения

Рис.1. Линейный рост НЛО коэфициента $\mathrm{d}_{33}$ с ростом концентрации хромофора в полимерной матрице.

\section{Лumepamypa}

[1] A.M. Sinyukov, M. R. Leahy, L. M. Hayden et al., Appl. Phys. Lett. 85, 5827 (2004).

[2] F.D.J. Brunner, S.-H. Lee, O-P. Kwon, and T. Feurer, Opt. Mater. Express 4, No. 8, 1586.

[3] A. Willets, S. Y. Nishimura, P. J. Schuck, R. J. Twieg, And W. E. Moerner, Acc. Chem. Res. 38, 549 (2005). 